\title{
Malgorzata Żbikowska*
}

\section{ZWROTY NIEDOOKREŚLONE CHARAKTERYZUJĄCE STAN ZDROWIA PSYCHICZNEGO OSKARŻONEGO A MOŻLIWOŚĆ ZASTOSOWANIA OBRONY OBLIGATORYJNEJ}

\section{Streszczenie}

Niniejszy szkic prezentuje analizę przesłanek obrony obligatoryjnej, o których mowa w treści przepisu art. 79 k.p.k., a zwłaszcza $§ 1$ pkt 4, z perspektywy językowej. Wskazany przepis prawny zawiera tzw. zwroty niedookreślone, charakteryzujące stan zdrowia psychicznego oskarżonego, których identyfikacja w konkretnym procesie karnym obliguje organ procesowy do wyznaczenia obrońcy z urzędu. Autorka podejmuje analizę z punktu widzenia poprawności językowej użytych w art. 79 k.p.k. zwrotów językowych, a swoje rozważania osadza na tle problematyki związanej ze stanowieniem i stosowaniem prawa.

Słowa kluczowe: oskarżony, obrona obligatoryjna, zwroty niedookreślone, ocenność pojęć, stan zdrowia psychicznego

\section{Uwagi wprowadzające}

Analiza przesłanek obrony obligatoryjnej, sklasyfikowanych w treści przepisu art. 79 k.p.k., była dokonywana w literaturze karnoprocesowej wielo-

* dr Małgorzata Żbikowska, Wydział Prawa i Administracji Uniwersytetu Szczecińskiego, adres e-mail: malgorzata.zbikowska@wpiaus.pl 
krotnie ${ }^{1}$. Odnajdujemy także bogate orzecznictwo sądowe w tym przedmiocie. Rozważania te dotyczą zarówno aspektu stosowania prawa, a więc takiego działania organu procesowego, które polega na zastosowaniu określonego przepisu prawnego do określonego stanu faktycznego sprawy, a także aspektu związanego z interpretacją tego przepisu prawnego. Poniżej została zaprezentowana próba rozważenia zagadnienia związanego ze stosowaniem obrony obligatoryjnej na podstawie przepisu art. 79 k.p.k. z nieco innej perspektywy badawczej. Tą perspektywą będzie kontekst językowy zwrotów niedookreślonych, które - we wskazanym przepisie prawnym - występują. Przy czym skoncentrowano się głównie na analizie treści przepisu art. $79 \S 1$ pkt 4 k.p.k. Przyjęta optyka badawcza nie pozostaje w sprzeczności do tej, która została już zaprezentowana w literaturze dogmatyczno-prawnej. Wręcz przeciwnie, ma ona w założeniu stanowić jej uzupełnienie. Impulsem dla podjęcia zaprezentowanego tematu ze wskazanej perspektywy badawczej była nowelizacja kodeksu postępowania karnego z 2013 roku (która weszła w życie w 2015 r.) 2 $^{2}$ Na mocy tejże nowelizacji doszło bowiem do istotnej zmiany treści przepisu art. 79 k.p.k. właśnie z perspektywy językowej, rzutującej na aspekt stosowania prawa. W uzasadnieniu projektu do nowelizacji z 2013 roku wskazywano ${ }^{3}$, iż zasadniczym celem zmian było usunięcie wątpliwości i trudności związanych z jego wykładnią, jak również wyeliminowanie mankamentu, który polegał na odniesieniu użytego w dotychczasowej treści przepisu art. $79 \S 4$ k.p.k. pojęcia poczytalności nie tylko do chwili popełnienia czynu, lecz także do czasu trwania postępowania karnego ${ }^{4}$.

Językowa analiza treści przepisu art. 79 k.p.k. pozwala na uznanie, że zawiera on w swojej treści kilka pojęć niedookreślonych, które wymagają bliż-

1 Zob. np. R.A. Stefański, Obrona obligatoryjna w polskim procesie karnym, Warszawa 2012; R.A. Stefański,, Obrona obligatoryjna po 1 lipca 2015 r., w: Obrońca i petnomocnik w procesie karnym po 1 lipca 2015 r. Przewodnik po zmianach, red. P. Wiliński, Warszawa 2015, s. 27-45; A. Ziębiński, Wybrane kontrowersje wokół obrony obligatoryjnej (cz. I), „Palestra” 2007, nr 1-2, s. 60-75; R. Kmiecik, O poczytalności oskarżonego ,w czasie postępowania”- polemicznie, „Palestra" 2007, nr 5-6, s. 92 - 96; M. Zbrojewska, Obrona obligatoryjna zwiazana ze stanem psychiki oskarżonego (refleksje wokót art. 79 § 4 k.p.k.), w: Księga jubileuszowa Profesora Janusza Tylma$n a$, red. T. Grzegorczyk, Warszawa 2011, s. 437-450; D. Świecki, Czynności procesowe obrońcy i petnomocnika $w$ sprawach karnych, Warszawa 2016, s. 64-71; R.A. Stefański, Ustanie obrony obowiązkowej, „Państwo i Prawo” 2007, z. 9, s. 68-76.

2 Ustawa z 27 września 2013 r. o zmianie ustawy - Kodeks postępowania karnego oraz niektórych innych ustaw (Dz.U. z 2013 r., poz. 1247). Nowelizacja weszła w życie 1 lipca 2015 r.

3 Uzasadnienie projektu Komisji Kodyfikacyjnej Prawa Karnego, s. 47; K. Dąbkiewicz, Kodeks postepowania karnego. Komentarz do zmian 2015, Warszawa 2015, s. 94.

4 K. Dąbkiewicz, op. cit., s. 94. 
szego scharakteryzowania, zaś pojawiające się na przestrzeni lat wątpliwości przy stosowaniu tego przepisu prawnego były związane właśnie z różną, językową jego interpretacją . Ponieważ wskazany przepis prawny ma niezmiernie istotne znaczenie z perspektywy stosowania prawa, a konkretnie konieczności - gdy zajdą przesłanki w nim wymienione - zastosowania obrony obligatoryjnej, a w konsekwencji także z perspektywy prawa do obrony oskarżonego, to wymaga rozważenia, czy posłużenie się przez ustawodawcę pojęciami niedookreślonymi w treści tegoż przepisu prawnego jest zasadne, a jeżeli tak, to jakie to ma znaczenie dla organów procesowych, a jakie dla oskarżonego. Analiza prawidłowości konstrukcji przepisu art. 79 k.p.k., jak i zresztą każdego przepisu prawnego, który w swej treści zawiera pojęcia niedookreślone, wydaje się konieczna, zwłaszcza wziąwszy pod uwagę kierowany pod adresem prawodawcy, a realizujący się na etapie tworzenia prawa postulat precyzji tekstów aktów prawnych ${ }^{6}$, polegający na posługiwaniu się przez prawodawcę przede wszystkim pojęciami jednoznacznymi, tak aby ich kontekst językowy nie budził żadnych wątpliwości. Jak wskazywano jednak w literaturze, precyzja tekstów aktów prawnych niejednokrotnie ustępuje miejsca tzw. adekwatności tekstu prawnego, przez którą rozumie się „dążenie do tego, aby tekst aktu prawnego wyrażał to, co chciał, by wyrażał jego twórca (prawodawca)"ᄁ. Adekwatność tekstu prawnego uzasadnia zatem posługiwanie się pojęciami niedookreślonymi w sytuacji, w której prawodawca nie chciał precyzyjnie określić jakiejś kwestii. Z kolei posługiwanie się przez prawodawcę pojęciami niedookreślonymi powinno mieć charakter intencjonalny, zaś wskazana celowość może być podyktowana chęcią uelastycznienia tekstu prawnego tak, aby, po pierwsze, odnosił się on do wielu różnych sytuacji, w tym także takich, które nie zostały przewidziane na etapie tworzenia tekstu prawnego, a po drugie, aby uwzględniał zmiany, które mogą nastąpić w odniesieniu do tejże regulacji prawnej w przyszłości ${ }^{8}$. Słowem, posługiwanie się przez ustawodawcę zwrotami niedookreślonymi nie jest

5 Do wątpliwości tych w dalszej części niniejszego szkicu jeszcze powrócę.

6 Szerzej w tym przedmiocie pisali S. Wronkowska, M. Zieliński, Zasady techniki prawodawczej. Komentarz, Warszawa 1997, s. 13 i n. Szeroko na temat słownictwa tekstów aktów prawnych pisała A. Chodun, Stownictwo tekstów aktów prawnych w zasobie leksykalnym wspótczesnej polszczyzny, Warszawa 2007. O precyzji tekstów aktów prawnych (a konkretnie kodeksu karnego) pisała J. Długosz, Ustawowa wyłaczność i określoność w prawie karnym, Warszawa 2016, s. 319-443.

7 A. Chodun, Klauzule generalne i zwroty niedookreślone - wybrane zagadnienia teoretyczne, w: A. Choduń, A. Gomułowicz, A. Skoczylas, Klauzule generalne i zwroty niedookreślone w prawie podatkowym i administracyjnym. Wybrane zagadnienia teoretyczne i orzecznicze, Warszawa 2013, s. 16.

8 Ibidem. 
błędem. Wprost przeciwnie, taki zabieg jest dopuszczalny, o ile towarzyszy mu określona intencja. Ponieważ jednak prawo karne procesowe (jak i w ogóle prawo karne sensu largo) ma charakter represyjny, a zatem związane jest z ogólnymi zasadami odpowiedzialności karnej oskarżonego, to powinno być także maksymalnie precyzyjne. Jednakże również na tle tej gałęzi prawa wykluczenie pojęć niedookreślonych wydaje się nie tylko niemożliwe, ale i niecelowe.

\section{Zwroty niedookreślone - założenia teoretycznoprawne}

Szczegółowa analiza treści przepisu art. 79 k.p.k., a ściślej aspektu językowego wybranych fragmentów tej regulacji prawnej, nie może obejść się bez wskazania pewnych ogólnych, teoretycznych podstaw, stanowiących punkt wyjścia dla dalszych rozważań. W pierwszej kolejności należy więc wskazać, jak w teorii prawa definiuje się zwroty wieloznaczne, niedookreślone (i nieostre) oraz ocenne ${ }^{9}$. Wyraźne rozgraniczenie tych pojęć ma niezmiernie istotne znaczenie także z tego względu, że w literaturze dogmatyczno-prawnej nierzadko dochodzi do posługiwania się nimi w sposób zamienny, co nie jest uprawnione. Ma to tym większe znaczenie, iż użycie niektórych z tych zwrotów w tekście aktu prawnego (posłużenie się nimi przez prawodawcę) jest błędem. Podstawą poniższej analizy są rozważania zaprezentowane przez A. Chodun ${ }^{10}-\mathrm{w}$ odniesieniu do zwrotów niedookreślonych (i nieostrych), a także rozważania zaprezentowane przez Z. Ziembińskiego ${ }^{11}-\mathrm{w}$ odniesieniu do zwrotów nieostrych i ocennych.

Wskazano już wcześniej, że jednym z podstawowych postulatów kierowanych do prawodawcy jest postulat precyzji języka tekstów aktów prawnych. Precyzja ta może zostać osiągnięta tylko wówczas, gdy zwroty używane w tekście prawnym są jednoznaczne, a zatem mają jedno znaczenie, są jasne i nie budzą wątpliwości ${ }^{12}$. Wskazywano także, że precyzja języka tekstów prawnych może

9 Warto zwrócić także uwagę, iż wśród zwrotów niedookreślonych znajdują się tzw. klauzule generalne, które związane są z odesłaniem pozasystemowym np. do zwyczajów lub obyczajów. Ponieważ analizowany w niniejszym szkicu przepis art. 79 k.p.k. nie zawiera w swojej treści klauzul generalnych, pomijam rozważania związane właśnie z tymi zwrotami. Więcej w przedmiocie klauzul generalnych zob. np. A. Choduń, Klauzule generalne..., s. 26-31.

10 Ibidem, s. 15-42.

11 Z. Ziembiński, O czym mówia prawnicy, gdy mówia o „ocenach”, „Państwo i Prawo” 1986, z. 12, s. 11-23.

12 Postulat precyzji tekstów aktów prawnych zawiera w sobie postulat, aby prawo było jasne. Zgodnie z założeniami S. Wronkowskiej ,(...) z jasnym prawem mielibyśmy do czynienia 
ustąpić postulatowi adekwatności takiego tekstu, w znaczeniu zaprezentowanym powyżej. Postulat adekwatności tekstu prawnego uzasadnia możliwość posłużenia się przez prawodawcę zwrotami niedookreślonymi, które pozostawiają pewien luz decyzyjny co do ich interpretacji. Jednakże zwroty niedookreślone, które pozostawiają margines interpretacji, nie są wieloznaczne, albowiem zwroty wieloznaczne to takie, które mają wiele możliwych do pomyślenia znaczeń (do zwrotów wieloznacznych zaliczamy np. słowo „zamek”, „miesięcznie” czy „klucz”) ${ }^{13}$. Zasadniczo wieloznaczność w tekście aktu prawnego jest błędem ${ }^{14}$. Prawodawca na etapie redagowania tekstu prawnego powinien więc eliminować wszelkie zwroty wieloznaczne oraz zastępować je zwrotami posiadającymi jedno znaczenie bądź - jeżeli takiej wieloznaczności nie da się uniknąć - powinien wprowadzić definicję legalną wieloznacznego zwrotu (jak np. definicję podejrzanego w treści przepisu art. $71 \S 1$ k.p.k.) albo w ostateczności umieścić określony wyraz w odpowiednim kontekście językowym ${ }^{15}$, a więc stosować określone tzw. determinatory kontekstowe, tak aby z całokształtu wypowiedzi jednoznacznie wynikało, jakie jest znaczenie wieloznacznego zwrotu, a zatem co prawodawca, tworząc tekst aktu prawnego, miał na myśli. Gdyby i tego prawodawca nie uczynił, interpretator tekstu prawnego powinien - w trakcie dokonywanego procesu wykładniczego - dokonać stosownej interpretacji tego zwrotu, tak aby ów zwrot posiadał tylko jedno znaczenie. Jednakże pozostawienie interpretatorowi tekstu

wówczas, gdyby: a) składały się nań wypowiedzi (normy postępowania) jednoznacznie i bezpośrednio nakazujące albo zakazujące pewnym podmiotom zachować się w określonych okolicznościach w określony sposób, b) przy czym wypowiedzi te byłyby jednoznaczne na gruncie języka powszechnego danej populacji (co gwarantowałoby ich komunikatywność dla wszystkich posługujących się językiem powszechnym)”. Przy czym Autorka kontynuowała, że tak rozumiana ,jasność prawa" nie jest w ogóle możliwa, ale stanowi pewną idealizację, do której należy się zbliżyć w sposób maksymalny z możliwych. Zob. S. Wronkowska, Problemy racjonalnego tworzenia prawa, Poznań 1982, s. 188.

13 Takie słowa inaczej nazywane są homonimami. Na popełniane błędy językowe, takie jak: ekwiwokacje czy amfibiologie, związane z wieloznacznością słów, zwracał już uwagę Z. Ziembiński, Logika praktyczna, Warszawa 2002, s. 137-142.

14 A. Choduń, Klauzule generalne..., s. 16. Przykłady nieporozumień językowych związanych z użyciem przez prawodawcę zwrotów wieloznacznych w tekstach aktów prawnych ukazała H. Jadocka, Przyczyny i skutki niejasności tekstów prawnych, w: Wspótczesny język prawny i prawniczy, red. A. Niewiadomski, A. Mróz, M. Pawelec, Warszawa 2007, s. 33-37. Ponadto Autorka wskazywała (s. 35), że „Użycie wyrazu wieloznacznego wymaga stosowania tzw. determinatorów kontekstowych, czyli dodatkowych określeń pozwalających skojarzyć wyraz z definicją właściwą dla danego kontekstu". Należy jednak wyrazić postulat, by prawodawca na etapie stosowania prawa w ogóle wyeliminował zwroty wieloznaczne, aby nie dochodziło w tym zakresie do żadnych nieporozumien.

15 A. Choduń, Klauzule generalne..., s. 17. 
prawnego takiej swobody interpretacyjnej niesie za sobą pewne ryzyko, albowiem wielość interpretatorów może implikować wielość różnych interpretacji, co - w tym wypadku - pozostaje zjawiskiem wysoce niepożądanym.

Od wieloznaczności należy wyraźnie oddzielić niedookreśloność. Jak wskazywała A. Choduń:

\begin{abstract}
Niedookreśloność dotyczy treści nazwy i polega na tym, że treść tej nazwy nie jest dostatecznie jasno przedstawiona. (...) Treścią jakiejś nazwy jest bowiem taki zespół cech, na podstawie którego osoba używająca danej nazwy we właściwy dla określonego języka sposób gotowa jest uznać jakiś dowolny przedmiot za desygnat tej nazwy, jeśli stwierdzi w nim te cechy łącznie, a przy braku którejkolwiek z nich - odmówić mu charakteru desygnatu tej nazwy. Przy czym niedookreśloność jakiejś nazwy może występować albo w relacji do jakiejś osoby, która nie potrafi wskazać tego zespołu cech, albo w relacji do języka - zachodzi ona wtedy, gdy słownikowa treść jakiejś nazwy jest niepełna, a jednocześnie nie stanowi zespołu konstytutywnego cech lub też wprawdzie stanowi taki zespół cech, ale któraś z nich jest niediagnostyczna (tzn. że jest tak określona, iż nie da się jednoznacznie stwierdzić, czy można ją przypisać jakiemuś przedmiotowi, czy nie) ${ }^{16}$.
\end{abstract}

Gdy jakaś nazwa jest jednoznaczna, to potrafimy zidentyfikować wszystkie cechy tejże nazwy i jednocześnie nie mamy trudności w uznaniu, że jakiś, np. widziany przez nas przedmiot jest desygnatem tej nazwy. Tytułem przykładu, nazwa „słoń” jest jednoznaczna językowo. „Słoń” jest definiowany jako „największe zwierze lądowe o grubej, nieowłosionej skórze, długiej, chwytnej trąbie i wystających siekaczach, żyjące w Afryce i Indiach" ${ }^{17}$. Przy założeniu, że nie widziałam większego zwierzęcia (ssaka) od tego, na które spoglądam, a ponadto przy założeniu, że wiem, czym jest trąba, a także czym są siekacze, nie mam problemu z identyfikacją stojącego nieopodal ssaka jako słonia, nawet jeżeli go wcześniej nigdy nie widziałam. Zgoła odmienna sytuacja ma miejsce z nazwami niedookreślonymi, których jasno nie da się zidentyfikować. Przykładowo słowo „uzasadniony” (przymiotnik ${ }^{18}$ ) oznacza „oparty na obiektywnych racjach”19.

16 Ibidem, s. 17-18.

17 L. Drabik, A. Kubiak-Sokół, E. Sobol, L. Wiśniakowska, Słownik języka polskiego PWN, Warszawa 2006, s. 926. sadniać".

18 Słowo „uzasadniony” może być bowiem także imiesłowem biernym od czasownika „uza-

19 L. Drabik, A. Kubiak-Sokół, E. Sobol, L. Wiśniakowska, op. cit., s. 1111. 
Definicja słowa „uzasadniony” nie wskazuje jednoznacznej treści, ale przybliża nam sposób jej rozumienia. Dlatego też pojęcie to ma charakter niedookreślony. Przykładowo, użyte w treści przepisu art. 303 k.p.k. określenie „uzasadnione podejrzenie" zostało wprowadzone przez prawodawcę rozmyślnie po to, aby pozostawić pewien luz decyzyjny (organów procesowych), co posiada przymiot uzasadnionego podejrzenia, a co nie.

Wydaje się, iż w tekstach aktów prawnych niedookreśloność jakiejś nazwy ma szczególnie istotne znaczenie w relacji do języka, gdy słownikowa treść jakiejś nazwy bądź nie przedstawia zespołu konstytutywnych cech tej nazwy, bądź przedstawia zespól konstytutywnych cech tej nazwy, jednakże jedna lub więcej takich cech jest niediagnostyczna. W powyżej zaprezentowanym przykładzie „uzasadniony”, tj. „oparty na obiektywnych racjach", ową cechą, której nie da się jednoznacznie stwierdzić, czy można ją przypisać jakiemuś przedmiotowi, czy nie, jest „obiektywna racja”. Określenie „obiektywna racja”, przesądzające, kiedy możemy mówić, że coś jest uzasadnione, a kiedy nie, sprawia, iż treść tej nazwy jest niewyraźna. Należy podkreślić raz jeszcze, iż nie oznacza to jednak, że należałoby wyrugować takie określenia $\mathrm{z}$ tekstów aktów prawnych (np. z kodeksu postępowania karnego), użytych $w$ takich aktach prawnych w charakterze intencjonalnym. Pozostawienie pewnego luzu interpretacyjnego organom procesowym jest bowiem - dla prawidłowego stosowania prawa - niejednokrotnie konieczne.

W literaturze teoretycznoprawnej podkreślano także, że niedookreśloność pociąga za sobą nieostrość nazwy ${ }^{20}$, przy czym:

Nieostrość zakresu wiąże się z tym, iż niektóre nazwy nie mają wyraźnej treści, to znaczy, iż nawet ten, kto dobrze zna dany język nie umiałby podać takiego zespołu cech, które pozwoliłoby w sposób stanowczy odróżniać desygnaty danej nazwy od jej przedmiotów ${ }^{21}$.

Wydaje się, iż nieostrość związana jest często z nazwami abstrakcyjnymi, a zatem takimi, które nie reprezentują żadnych obiektów fizycznych ${ }^{22}$. Nieostrość nazwy wiąże się z brakiem konstytutywnych cech danej nazwy, które pozwala-

20 A. Choduń, Klauzule generalne..., s. 18.

21 Z. Ziembiński, Logika..., s. 36.

22 Takim pojęciem abstrakcyjnym może być np. słowo „miłość”, „sprawiedliwość”, a na gruncie kodeksu postępowania karnego „,prawdopodobieństwo” (art. 249 k.p.k.) czy „godność” (art. $2 \S 1$ pkt 3 k.p.k.). 
łyby przesądzić, co jest, a co nie jest desygnatem tej nazwy. Przy czym niemożność wskazania takich konstytutywnych cech nie jest związana z nieznajomością języka, w którym ta nazwa została wysłowiona, ale związana jest z obiektywnym brakiem takich cech (zamkniętego katalogu takich cech). Przykładowo nazwa „ciepły” jest nieostra, ponieważ ustalenie zakresu tej nazwy może powodować pewne trudności. Kiedy powiemy np., że woda jest ciepła, a kiedy, że jest letnia lub gorąca? Od ilu stopni Celsjusza możemy powiedzieć, że woda jest ciepła, a od ilu, że już gorąca? Czy będzie to 20, 25, 30, 35, 40, 45 stopni? Pewne nazwy zatem z założenia są nieostre. Przekształcenie nazwy nieostrej w nazwę ostrą mogłoby nastąpić w razie konwencjonalnego ustalenia (przesądzenia) zakresu takiej nazwy (np. gdybyśmy konwencjonalnie uznali, że przez ciepłą wodę rozumie się wodę w temperaturze od 20-40 stopni Celsjusza), choć w wielu przypadkach (tak jak i we wskazanym przypadku) jest to w ogóle niecelowe ${ }^{23}$.

Agnieszka Choduń charakteryzując nieostrość nazwy, wskazywała, że te przedmioty, co do których istnieją wątpliwości, czy zakwalifikować je jako desygnat albo niedesygnat danej nazwy, znajdują się w tzw. pasie nieostrości nazwy. W literaturze wskazywano, że:

Wśród nazw nieostrych znajdują się także takie, które mają dwa pasy nieostrości - dolny pas nieostrości i górny pas nieostrości. Przykładem takiej nazwy jest nazwa „średni” (...). Występowanie w testach aktów prawnych nazw nieostrych i niedookreślonych sprawia, że tekst staje się „bardziej uniwersalny do odczytania". (...) prawodawca daje interpretatorowi luz co do odczytania nazwy nieostrej (luz interpretacyjny). Przy czym nie jest to ani swoboda, ani tym bardziej dowolność w tym zakresie. W każdej sytuacji wystąpienia w tekście aktu prawnego nazwy nieostrej interpretator musi rozeznać, jaki jest zakres nazwy oraz czy ma ona jeden czy dwa pasy nieostrości. Interpretator musi ustalić: 1) dolną i górną granicę tego pasa - jeśli nazwa ma jeden pas nieostrości, 2) dla każdego z pasów z osobna granice (górną granicę pasa nieostrości i dolną granicę pasa nieostrości) - jeśli nazwa ma dwa pasy ${ }^{24}$.

23 Nie oznacza to jednak, że w tekstach aktów prawnych likwidowanie nieostrości poprzez tworzenie pewnych granic jest zawsze niecelowe. Wprost przeciwnie, czasem ma ono znaczenie. Tak też postąpił ustawodawca, określając w kodeksie karnym, a ściślej w jego przepisie art. $115 \S 5$ k.k., czym jest mienie znacznej wartości, pisząc, że „Mieniem znacznej wartości jest mienie, którego wartość w czasie popełnienia czynu przekracza 200000 złotych”. Na pewne wady takiego rozwiązania - właśnie w odniesieniu do mienia znacznej wartości - wskazywał W. Wolter, Uwagi o znamionach wymagajacych ilościowej oceny w przepisach prawa karnego, „Państwo i Prawo" 1976, nr 6, s. 26.

24 A. Choduń, Klauzule generalne..., s. 18-20. 
Innymi słowy, wprowadzenie przez prawodawcę do tekstu prawnego zwrotu nieostrego ma charakter celowy, zaś owa celowość sprowadza się do przyznania organowi procesowemu luzu interpretacyjnego co do odczytania takiej nazwy nieostrej, a zatem takiego luzu, który płynie z właściwości języka prawnego. Luz interpretacyjny nie jest - jak to powyżej wskazano - nieograniczoną dowolnością interpretacyjną. A zatem luz interpretacyjny to pewna swoboda organu procesowego co do ustalenia znaczenia nazwy niedookreślonej (nieostrej), ukształtowana w określonych granicach. Luz interpretacyjny wiąże się więc z wykładnią prawa, zaś u podłoża wyboru jednego $\mathrm{z}$ dwóch czy kilku znaczeń interpretowanego zwrotu leży dokonana przez organ procesowy ocena tego zwrotu ${ }^{25}$. Granice luzu interpretacyjnego wyznacza np. wiążąca wykładania przepisów prawa, doktryna czy orzecznictwo sądowe ${ }^{26}$.

Zwroty niedookreślone należy wyraźnie oddzielić od zwrotów ocennych ${ }^{27}$.

Dlatego też czynności, których dokonuje interpretator w związku ze zwrotem niedookreślonym (a zatem również nieostrym), nie są ocenianiem. Ocenianie związane jest bowiem z oceną, a więc przeżyciem aprobaty albo dezaprobaty dla jakiegoś stanu rzeczy jako dobrego albo złego ${ }^{28}$.

Czynności związane z pojęciami niedookreślonymi to czynności związane z wykładnią, a także ze swobodą decyzyjną podejmowaną w ramach luzu interpretacyjnego. Z kolei pojęcia ocenne to zwroty wyrażające ocenę określonego stanu rzeczy, a więc preferencję określonego podmiotu odnoszącą się do określonego stanu rzeczy. Może być to zarówno przeżycie jakiejś oceny, ale też wypowiedź

25 O luzie interpretacyjnym pisał J. Wróblewski, uznając, że: „Luz interpretacyjny wiąże się z rolą, jaką w wykładni prawa odgrywają oceny. Chodzi tutaj o wykładnię operatywną, której dokonuje organ stosujący prawo wtedy, gdy ustalenie znaczenia stosowanych przepisów prawnych budzi w konkretnej sytuacji wątpliwości. Istnieje wówczas luz w określeniu, czy wątpliwości te są, czy też lex est clara, istnieją luzy doboru dyrektyw interpretacyjnych pierwszego stopnia, luzy w sposobie posługiwania się tymi dyrektywami, luzy w wyborze i użyciu dyrektyw interpretacyjnych drugiego stopnia, prowadzących do określonych preferencji znaczeń, a w związku z tym do wykładni rozszerzającej lub zwężającej”. Tak: J. Wróblewski, Kontrola decyzji sądowej - wybrane zagadnienia teoretyczne, „Państwo i Prawo” 1976, z. 8-9, s. 20. Warto zwrócić uwagę, iż luz interpretacyjny jest tylko jednym z kilku luzów decyzyjnych. Do innych luzów decyzyjnych J. Wróblewski zaliczył także (s. 19-21) luz walidacyjny, luz dowodowy oraz luz wyboru konsekwencji.

26 Ibidem, s. 22-23.

$27 \mathrm{Na}$ pewne nieporozumienia w mylnym rozpoznawaniu pojęć ocennych i pojęć niedookreślonych zwracał uwagę Z. Ziembiński, O czym mówia prawnicy..., s. 11.

28 A. Choduń, Klauzule generalne..., s. 22-23. 
wyrażająca ocenę lub nawet wypowiedź opisująca daną ocenę ${ }^{29}$. To jedynie kontekst wypowiedzi może niekiedy wskazywać na jej status semiotyczny. Ocena danego stanu rzeczy albo ma charakter oceny globalnej, a zatem wieloaspektowej (dokonywanej z różnych punktów widzenia), albo ma charakter oceny preferencyjnej, a zatem takiej, która przy porównywaniu dwóch stanów rzeczy przyznaje większą wartość jednemu z nich ${ }^{30}$. Warto zwrócić także uwagę, iż ocena ma charakter niejako następczy, tzn. najpierw podmiot decyzyjny, zobowiązany do wydania jakiegoś rozstrzygnięcia, podejmuje czynności związane z ustaleniem znaczenia tego pojęcia, również - jeżeli istnieje taka potrzeba - z ustaleniem tego pojęcia w ramach luzu decyzyjnego, a dopiero w następnej kolejności czynności związane z dokonaniem oceny, czy określony stan rzeczy spełnia wyznaczone już kryteria tego pojęcia. Co istotne, dokonywanie takich zabiegów chyba zasadniej jest uznać za kwalifikowanie, a nie ocenianie, albowiem jeżeli wskazuję, że ze względu na cechy jakiejś nazwy jestem w stanie uznać, że $\mathrm{X}$ jest desygnatem tej nazwy, to w gruncie rzeczy nie dokonuję oceny $\mathrm{X}-\mathrm{a}$, a jedynie - na podstawie czynności intelektualnej - uznaję (kwalifikuję) X za desygnat tej nazwy ${ }^{31}$.

\section{Zwroty niedookreślone charakteryzujące stan zdrowia psychicznego oskarżonego - aspekt stosowania prawa}

Biorąc pod uwagę powyżej poczynione ustalenia, można dokonać próby ich przełożenia na treść przepisu art. 79 k.p.k. (na wybrane jego fragmenty) w zakresie, w jakim ów przepis prawny stanowi o zwrotach niedookreślonych. Na wstępie należy jednak zwrócić uwagę, że przepis art. 79 k.p.k. w swojej treści zawiera zarówno nazwy jednoznaczne, określone i ostre, jak i nazwy niedookreślone i nieostre. Nie może budzić wątpliwości, iż $§ 1$ pkt 1 i 2 art. 79 k.p.k. zawiera w swojej treści nazwy ostre $^{32}$, a przy tym i jednoznaczne. Precyzyjnie jesteśmy bowiem w stanie określić,

29 Z. Ziembiński, O czym mówia prawnicy..., s. 13. Autor w przywołanym artykule szeroko charakteryzował kwestie związane z ocenami w prawie. Zob. także idem, Problemy podstawowe prawoznawstwa, Warszawa 1980, s. 13.

30 Z. Ziembiński, O czym mówią prawnicy..., s. 12.

31 Słowem uznaję, że dokonanie oceny poprzedza kwalifikowanie, a więc najpierw dochodzi do ustalenia znaczenia danego zwrotu. W przypadku luzów decyzyjnych podstawą do ustalenia znaczenia zwrotu niedookreślonego może być ocena podmiotu dokonującego takich ustaleń, a dopiero w następnej kolejności kwalifikacja określonego stanu rzeczy pod dokonane ustalenia.

32 Przy czym, jak stwierdził Z. Ziembiński: „Nazwy stają się nazwami ostrymi dzięki temu, że są nazwami wyraźnymi - to znaczy, umiemy podać zespół cech wystarczających dla odróżnienia desy- 
kiedy osoba nie ukończyła 18 lat, a także kim jest osoba głucha, niema i niewidoma, a zatem osoba całkowicie pozbawiona zmysłu słuchu, mowy lub wzroku. Są to nazwy ostre, ponieważ wszystkie istniejące podmioty (a więc i takie, które uzyskały status oskarżonego/podejrzanego) jesteśmy w stanie - w oparciu o te kryteria - podzielić na dwie grupy: grupę podmiotów, które niewątpliwie są desygnatami nazwy „osoba, która nie ukończyła 18 lat”, „głuchy”, „niemy”, „niewidomy”, oraz grupę podmiotów, które niewątpliwie nie są desygnatami nazwy „osoba, która nie ukończyła 18 lat”, „głuchy”, „niemy”, „niewidomy”. Można określić, iż nazwy ostre dzielą świat w kategoriach 0-1. Nie zawsze tak jednak bywa. Zwróćmy zatem uwagę na pozostałe - wybrane - fragmenty tego przepisu prawnego.

Wskazana jednostka redakcyjna - ściślej art. 79 § 1 pkt 3 i 4 k.p.k. ${ }^{33}$ - nacechowana jest wieloma pojęciami niedookreślonymi, zaś jednym z nich jest zwrot „uzasadniona wątpliwość”. W literaturze dogmatycznoprawnej wskazywano, że:

„uzasadnione wątpliwości”, to takie, które oparte są na konkretnych okolicznościach i dowodach i muszą wynikać z oceny owych dowodów i okoliczności ustalonych $\mathrm{w}$ sprawie, oceny dokonanej przez uprawniony organ procesowy na wniosek stron lub z urzędu. Sąd ustalając, czy faktycznie występują

gnatów danej nazwy od innych przedmiotów, lub też dzięki temu, że są nazwami dla nas intuicyjnymi - to znaczy, że na podstawie ogólnego wyglądu danego przedmiotu, bez zastanawiania się nad treścią danej nazwy, umiemy określić, czy jest on, czy nie jest desygnatem tej nazwy" - idem, Logika ..., s. 36.

33 Należy zwrócić uwagę, iż wskazany szkic ograniczyłam niemal wyłącznie do analizy treści przepisu art. $79 \S 1$ pkt 4 k.p.k. Nie oznacza to jednak, że pozostałe fragmenty tego przepisu prawnego (np. jego § 3) nie zawierają zwrotów niedookreślonych. Wręcz przeciwnie. Również art. $79 \S 1$ pkt 3 k.p.k. charakteryzuje się występowaniem w nim zwrotów niedookreślonych, takich jak ,wyłączenie lub w znacznym stopniu ograniczenie zdolności rozpoznania znaczenia czynu lub pokierowania swoim postępowaniem". Ponieważ jednak owe zwroty niedookreślone zostały scharakteryzowane na gruncie kodeku karnego (zob. art. 31 k.k.), to zasadniczo różnią się od zwrotów określonych w pkt 4 tego przepisu prawnego. Analizę pewnych wątpliwości, które pojawiały się w związku z interpretacją art. 79 § 1 pkt 3 k.p.k. (przed zmianami k.p.k.), można odnaleźć w wielu opracowaniach naukowych. Zob. np. R. Kmiecik, op. cit., s. 92-96. A. Płatek, Poczytalność oskarżonego „w czasie postępowania” czy psychiczna zdolność „, do rozumnej obrony”, „Palestra” 2009, nr 5-6, s. 70-75. Warto także zwrócić uwagę na stanowisko W. Woltera, który odnosił się do nieostrości zwrotów charakteryzujących stan zdrowia psychicznego sprawcy czynu zabronionego. Autor pisał: „Praktycznie szczególnie ważne jest »znaczne ograniczenie rozpoznania znaczenia czynu lub kierowania postępowaniem«, co wiąże się z ocenami psychiatryczno-psychologicznymi, z kwestią z natury rzeczy bardzo delikatną. Od ustalenia na temat znaczności zależeć będzie, czy oskarżony odpowiadać będzie jako w pełni odpowiedzialny przy braku zakłóceń lub przy zakłóceniach, które nie są znaczne, albo jako nie w pełni odpowiedzialny w powodu znacznych zakłóceń, co otwiera drogę do nadzwyczajnego złagodzenia kary, a zarazem do stosowania środków zabezpieczających. Praktyka wskazuje, jak częste są wypadki niepełnej sprawności psychicznej przy braku tylko znaczności w zakłóceniu, a nie zakłócenia w ogóle. Cały więc ciężar spoczywa właśnie na tym jednym ilościowo ocennym elemencie, który chce wiele powiedzieć, ale mało powiedzieć może". W. Wolter, Uwagi o znamionach..., s. 27. 
przesłanki wskazane w art. $79 \S 1$ pkt 3 i 4 k.p.k., zawsze powinien pamiętać o tym, że ich „zachodzenie” nie jest warunkowane jakimś abstrakcyjnym przeświadczeniem czy niezbyt uchwytnym domysłem, lecz uzależnione jest od powzięcia przez organ postępowania tylko takich wątpliwości, które mają charakter uzasadniony, a więc takich, które mają oparcie w konkretnych ustalonych w sprawie okolicznościach ${ }^{34}$.

Wydaje się, iż oba pojęcia składające się na zwrot „uzasadnione wątpliwości” nie mogą być jasno sprecyzowane. Określenie „wątpliwość” jest pojęciem nieostrym, albowiem nie ma ono wyraźnej treści. Trudno bowiem jednoznacznie ustalić, co nie jest wątpliwością, a co nią już jest. Ponadto wcześniej wyartykułowano już, że zwrot „uzasadniony” jest zwrotem niedookreślonym oraz definiowany jest jako „oparty na obiektywnych racjach”. Z kolei określenie „oparty na obiektywnych racjach” posiada dwuaspektowy charakter - obiektywny i subiektywny. Po pierwsze, są to subiektywne racje organu procesowego, który podejmuje stosowne rozstrzygnięcie - w tym wypadku będzie to rozstrzygnięcie co do przyznania obrony obligatoryjnej w procesie karnym. Racje organu procesowego wiążą się z przyznanym mu luzem decyzyjnym oraz - występującą w ramach tego luzu - swobodą takiego przekonania (posiadania wątpliwości - ogólnie rzecz ujmując - co do stanu zdrowia psychicznego oskarżonego $)^{35}$. Po drugie, owe racje organu procesowego o charakterze subiektywnym powinny być obiektywnie weryfikowalne. Rzeczona obiektywna weryfikowalność może mieć miejsce tylko i wyłącznie wówczas, gdy racje stanowiące podstawę wydania określonej decyzji procesowej są uzasadnione. Uzasadnienie podjętej decyzji procesowej

34 K. Dąbkiewicz, op. cit., s. 105-106.

35 Zatem uzasadnione wątpliwości to wątpliwości organu procesowego. Choć wydaje się to oczywiste, to jednak, jak wskazała M. Zbrojewska „W orzecznictwie pojawił się pogląd co do potrzeby zasięgania przez organ procesowy »wstępnej opinii« odnośnie do tego, czy istniejące w sprawie okoliczności rzeczywiście czynią wątpliwości co do poczytalności »uzasadnionymi«, przy czym chodziłoby tu o zasięganie opinii na zasadach ogólnych (art. 193 § 1 k.p.k.), a nie opinii psychiatrycznej w rozumieniu art. 202 k.p.k. Pogląd ten nie jest jednak trafny. Organ procesowy od razu, na podstawie art. 202 § 1 k.p.k., powinien zwrócić się do biegłych lekarzy psychiatrów o wydanie opinii o stanie zdrowia psychicznego, skoro powziął wątpliwości co do poczytalności oskarżonego. Wstępne weryfikowanie zasadności tych wątpliwości jest chybione, skoro organ procesowy ma wątpliwości co do poczytalności oskarżonego to oznacza, że są one rzeczywiste i uzasadnione, bowiem coś przesądza, że wątpliwości te się pojawiają”. M. Zbrojewska, op. cit., s. 445. Należy zgodzić się z wyrażonym powyżej poglądem M. Zbrojewskiej, albowiem po to daje się organowi procesowemu luzy decyzyjne, aby z nich korzystał. Ewentualna konieczność powoływania biegłych tylko na okoliczność stwierdzenia tego, czy wątpliwości organu procesowego są uzasadnione, całkowicie pozbawiałaby organ procesowy przyznanego mu przez prawo luzu decyzyjnego oraz samodzielności jurysdykcyjnej. 
powinno być oparte na zgromadzonych w sprawie dowodach oraz logicznej argumentacji. Co za tym idzie, uzasadnione wątpliwości związane są z oceną organu procesowego, choć sam ten zwrot nie ma charakteru oceniającego. Ergo, przepis art. 79 k.p.k. zawiera w swojej treści niedookreślony i jednocześnie nieostry zwrot - „uzasadnione wątpliwości”, który związany jest z przyznanym organowi procesowemu luzem decyzyjnym. Nieostrość tego zwrotu wynika z faktu niemożności jednoznacznego przesądzenia, kiedy wątpliwości organu procesowego będą miały charakter uzasadniony, a kiedy nie. Wskazówki co do tego, czy wątpliwości organu procesowego są uzasadnione, gdy istnieje określona podstawa dowodowa, pozwalająca na wyrażanie takich wątpliwości, nie stanowią ani precyzyjnego zdefiniowania tego zwrotu, ani nie zmieniają jego charakteru językowego. Nie oznacza to jednak, że określenie to powinno zostać usunięte z kodeksu postępowania karnego.

Zgodnie z przepisem art. $79 \S 1$ pkt 4 k.p.k. oskarżony musi mieć obrońcę, jeżeli ,zachodzi uzasadniona wątpliwość, czy stan jego zdrowia psychicznego pozwala na udzial $w$ postępowaniu lub prowadzenie obrony w sposób samodzielny oraz rozsądny". Warto zwrócić uwagę, że wskazana jednostka redakcyjna została dodana do kodeksu postępowania karnego dopiero w 2015 r. W literaturze podkreślano, że „Przyjęta modyfikacja polega na rozdzieleniu podstaw obrony obligatoryjnej z powodu przesłanek występujących tempore criminis (art. $79 \S 1$ pkt 3 k.p.k.) oraz tempore procedendi (art. $79 \S 1$ pkt 4 k.p.k.) ${ }^{\prime 36}$. Co za tym idzie, ustawodawca przesądził, że wyżej zacytowana przesłanka odwołująca się do okoliczności tempore procedendi ma tak istotne znaczenie, że należy ją wyłuszczyć, niejako wydobyć z ogólnego, a użytego w treści art. 79 § 2 k.p.k. określenia „inne okoliczności utrudniające obronę”. Zgodnie ze wskazanym przepisem prawnym „oskarżony musi mieć obrońcę również wtedy, gdy sąd uzna to za niezbędne ze względu na inne okoliczności utrudniające obronę". Pojęcie „inne okoliczności utrudniające obronę” ma charakter niedookreślony. Ustawodawca bowiem nie tylko nie precyzuje owych okoliczności, ale nawet nie wskazuje ich dla przykładu. Owa niedookreśloność niewątpliwie uelastycznia tekst prawny w taki sposób, że po pierwsze nie tworzy zamkniętego katalogu okoliczności utrudniających obronę, a po drugie wskazany przepis prawny (§ 2 art. 79 k.p.k.) pozostanie zawsze aktualny, niezależnie od tego, jakie hipotetyczne sytuacje okoliczności utrudniających obronę pojawią się w przyszłości.

36 Tak: W. Posnow, w: Kodeks postępowania karnego. Komentarz, red. J. Skorupka, Warszawa 2016, s. 242. 
Zamieszczenie $\mathrm{w}$ treści przepisu art. 79 k.p.k. przesłanki obligującej do wyznaczenia obrony z urzędu, gdy zachodzi uzasadniona wątpliwość, czy stan zdrowia psychicznego oskarżonego pozwala mu na udział w postępowaniu lub prowadzenie obrony w sposób samodzielny oraz rozsądny, nie miało charakteru marginalnego. Podstawą dla takiej zmiany wskazanego przepisu prawnego były pojawiające się $\mathrm{w}$ doktrynie interpretacyjne wątpliwości związane $\mathrm{z}$ treścią ówczesnego (a zatem przed zmianą z 2015 r.) przepisu art. 79 k.p.k., który w $\S 1$ pkt 3 wskazywał, że oskarżony musi mieć obrońcę, gdy „zachodzi uzasadniona wątpliwość co do jego poczytalności”. Wskazane wątpliwości - niezmiernie istotne z perspektywy stosowania prawa - związane były z interpretacją niedookreślonego i nieostrego pojęcia „poczytalności”, wziąwszy pod uwagę ówczesną treść tego przepisu prawnego, a ściślej jego § 4, zgodnie z którym „Jeżeli w toku postępowania biegli lekarze psychiatrzy stwierdzą, że poczytalność oskarżonego zarówno w chwili popełnienia zarzuconego mu czynu, jak i w czasie postępowania nie budzi wątpliwości, udział obrońcy w dalszym postępowaniu nie jest obowiązkowy. Prezes sądu, a na rozprawie sąd, może wówczas cofnąć wyznaczenie obrońcy". Nie wnikając w tym miejscu głęboko w bliższą charakterystykę tych wątpliwości ${ }^{37}$, należy tylko wskazać, iż pojęcie ,poczytalności” zawsze było wiązane z treścią przepisu art. 31 k.k., przy czym ów przepis prawny dotyczył (i wciąż dotyczy) jedynie zdolności rozpoznania znaczenia czynu lub pokierowania swoim postępowaniem w czasie czynu (tempore criminis), zaś ówczesny przepis art. 79 k.p.k. stanowił także o „poczytalności w czasie postępowania”. Innymi słowy, pojęcie „poczytalności” było zawsze pojęciem materialnoprawnym, podczas gdy zmiana ówczesnego przepisu art. $79 \S 4$ k.p.k. wprowadziła (w sposób nieuzasadniony) pojęcie poczytalności również w znaczeniu ściśle procesowym. Pozostawiając całkowicie poza zakresem niniejszych rozważań ów - już zdezaktualizowany - problem interpretacyjny, warto tylko zaznaczyć, że jego istota sprowadzała się do wątpliwości związanych z pojęciem poczytalności. Co za tym idzie, niejednokrotnie wprowadzanie do kodeksu postępowania karnego pojęć niedookreślonych (i nieostrych) jest wysoce nie-

37 Wskazane wątpliwości były wyrażane przez licznych przedstawicieli polskiej doktryny. Niejednokrotnie poglądy te miały charakter odmienny. Zob. np. A. Ziębiński, op. cit., s. 60 i n.; R. Kmiecik, op. cit., s. 92 i n.; A. Płatek, op. cit., s. 70 i n.; M. Zbrojewska, op. cit., s. 437 i n.; R. Paprzycki, Glosa do wyroku SN z dnia 14 marca 2008r., II KK 404/04, „Palestra” 2005, nr 9-10, s. 246 i n.; E. Habzda-Siwek, Dylematy zwiazane z opinia o stanie zdrowia psychicznego oskarżonego (refleksje wokót art. 202 k.p.k.), w: Nauki penalne wobec problemów wspótczesnej przestępczości. Księga jubileuszowa z okazji 70 rocznicy urodzin Profesora Andrzeja Gaberle, red. K. Krajewski, Warszawa 2007, s. 187 i n. 
pożądane oraz może powodować więcej szkody aniżeli pożytku, ze względu na trudności w ich interpretacji. $Z$ tego też względu dokonane ustawą nowelizacyjną z 27 września 2013 r. zmiany treści przepisu art. 79 k.p.k. - biorąc pod uwagę powyżej zakreśloną problematykę - należy uznać za zasadne.

Powracając do głównego wątku rozważań, należy zaznaczyć, że zwroty „samodzielny” i „rozsądny” użyte w treści przepisu art. 79 k.p.k. są pojęciami niedookreślonymi, a nie ocennymi. Samodzielny to znaczy „niezależny od nikogo, niepotrzebujący niczyjej pomocy, niepodlegający czyjejś władzy", zaś rozsądny to „nacechowany rozsądkiem”, przy czym przez rozsądek rozumie się „zdolność rozumowego, trzeźwego ujmowania spraw, wydawania trafnych sądów"38. Wskazane zwroty są niedookreślone, ponieważ ich słownikowe definicje jednoznacznie nie precyzują ich treści, a jedynie przybliżają nam znaczenie tych nazw. Natomiast samo językowe określenie „rozsądny” czy „samodzielny” nie jest jeszcze dokonywaniem oceny, choć ten sam zespół słów może być czasem rozpoznawany jako opis, innym zaś razem jako ocena określonego stanu rzeczy. Ustalenie, z jaką wypowiedzią mamy do czynienia (jaki jest status semiotyczny wypowiedzi), zależy zatem od kontekstu wypowiadanych słów.

Dodanie do przepisu art. $79 \S 1$ k.p.k. punktu 4 w powyżej zaprezentowanym brzmieniu miało na celu - jak wynika z uzasadnienia projektu - „wprowadzenie kryterium zobiektywizowanego, a zarazem odwołującego się do pewnego wzorca przeciętnego zachowania, w którym istnieje faktyczna możliwość oceny własnego zachowania i realizacji przyznanych uprawnień" 39 . Uzasadnienie to nie niweluje jednak pewnych wątpliwości, które mogą pojawić się w związku z zastosowaniem tego przepisu prawnego. Jego poprawna analiza zależy bowiem także od analizy formalnej przepisu, a ściślej od analizy syntaktycznych połączeń, które w takim przepisie prawnym zostały wysłowione ${ }^{40}$. W pierwszej kolejności należy jednak zwrócić uwagę, że zwroty „samodzielny oraz rozsądny”

38 Znaczenie słów: „samodzielny”, „rozsądny” i „rozsądek” zaczerpnęłam z: L. Drabik, A. Kubiak-Sokół, E. Sobol, L. Wiśniakowska, op. cit., Warszawa 2006, s. 140. Należy zwrócić uwagę, iż w niniejszym szkicu całkowicie pomijam problematykę roli słowników w interpretacji tekstów prawnych. Więcej w tym przedmiocie zob. M. Zieliński, Wykładnia prawa. Zasady. Reguly. Wskazówki, Warszawa 2002, s. 315 i n.; A. Choduń, M. Zieliński, W sprawie stowników w procesie interpretacji tekstów prawnych raz jeszcze, „Państwo i Prawo” 2008, z. 7, s. 96-100.

39 Z uzasadnienia projektu Komisji Kodyfikacyjnej Prawa Karnego za K. Dąbkiewiczem, op. cit., s. 102.

40 Analizę syntaktycznych połączeń wysłowionych w przepisach kodeksu karnego poczynił W. Wolter, Z problematyki języka prawnego kodeksu karnego, „Krakowskie Studia Prawnicze” 1972, rok V, s. 3-31. 
wiązane są ze stanem zdrowia psychicznego oskarżonego, z kolei stan zdrowia psychicznego może dotyczyć wszelkich zakłóceń czynności psychicznych oskarżonego w trakcie postępowania karnego, a zatem chorób psychicznych, zaburzeń psychicznych niebędących chorobami psychicznymi, czy dysfunkcji stanu psychicznego o charakterze trwałym lub przemijającym. Skala takich zakłóceń nie jest sprecyzowana. $Z$ kolei czasowość ich występowania może implikować także zawieszenie postępowania karnego (zob. art. 22 k.p.k.). Ponadto zwroty „samodzielny oraz rozsądny" mogą być wiązane z „udziałem w postępowaniu” lub z „prowadzeniem obrony”. Słowo „lub" użyte we wskazanym przepisie prawnym jest przejawem alternatywy nierozlącznej (zwykłej), zaś:

warunkiem wystarczającym prawdziwości alternatywy zwykłej jest prawdziwość choćby jednego argumentu zdaniowego (prawdziwość obu zdań składowych nie jest konieczna). Natomiast warunkiem wystarczającym i zarazem koniecznym fałszywości alternatywy zwykłej jest fałszywość obu zdań składowych. Jeżeli kolejno znakiem alternatywy nierozłącznej łączymy kilka zdań, to dla prawdziwości całego takiego zdania złożonego wystarcza prawdziwość przynajmniej jednego zdania składowego, zaś dla fałszywości całego zdania konieczna jest fałszywość wszystkich zdań składowych ${ }^{41}$.

W związku z tym wskazany przepis prawny należałoby podzielić na dwie części - po pierwsze, obrona obligatoryjna może mieć miejsce, gdy zachodzi uzasadniona wątpliwość, czy stan zdrowia psychicznego oskarżonego pozwala na jego udział w postępowaniu w sposób samodzielny oraz rozsądny, a po drugie, gdy zachodzi uzasadniona wątpliwość, czy stan zdrowia psychicznego oskarżonego pozwala mu na prowadzenie obrony w sposób samodzielny oraz rozsądny, przy czym dla zastosowania obrony obligatoryjnej w oparciu o przepis art. $79 \S 1$ pkt 4 k.p.k. wystarczy wypełnienie tylko jednego z tych warunków, zaś dla niemożności skorzystania z obrony obligatoryjnej na tej podstawie wymagane jest lączne niewypełnienie obu warunków. Pierwsza z powyżej wskazanych sytuacji, a zatem gdy istnieje uzasadniona wątpliwość, czy oskarżony ze względu na swój stan zdrowia psychicznego może brać udział w postępowaniu w sposób samodzielny oraz rozsądny, ma miejsce, gdy istnieją pewne wątpliwości co do samej kwestii udziału oskarżonego w postępowaniu, a więc co do tego, czy ze względu na stan zdrowia psychicznego może być on w ogóle obecny w postępowaniu. Przy czym nie tyle dotyczy to obecności fizycz-

41 Z. Ziembiński, Logika.., s. 79. 
nej, ale pewnych predyspozycji psychicznych oskarżonego ${ }^{42}$. Z kolei druga sytuacja, a więc gdy istnieją uzasadnione wątpliwości co do tego, czy oskarżony ze względu na swój stan zdrowia psychicznego może prowadzić obronę w sposób samodzielny oraz rozsądny, ma miejsce, gdy oskarżony co prawda może brać udział w postępowaniu, ale nie może / nie potrafi się bronić ${ }^{43}$. Owa niemożność bronienia się musi jednak wypływać ze złego stanu zdrowia psychicznego oskarżonego. Konieczność wyznaczenia obrony obligatoryjnej w oparciu o obie wskazane przesłanki stanowi przejaw prawa do obrony oskarżonego.

Zaprezentowana powyżej wykładnia analizowanego przepisu prawnego w zakresie, w jakim pozwala ona na separację dwóch wskazanych sytuacji, a więc osobno sytuacji związanej z udziałem oskarżonego w postępowaniu oraz sytuacji związanej z prowadzeniem obrony, została oparta na przyjmowanym w logice znaczeniu słowa „lub”, reprezentującego alternatywę nierozłączną. Warto także zwrócić uwagę, iż taka wykładnia jest wykładnią korzystną dla oskarżonego, ponieważ - powołując się na treść przepisu art. 79 § 1 pkt 4 k.p.k. - nie trzeba wykazywać, że stan zdrowia psychicznego oskarżonego nie pozwala na udział w postępowaniu i na prowadzenie obrony w sposób samodzielny i rozsądny, ale można jedynie wykazywać, że oskarżony nie jest w stanie prowadzić obrony w sposób samodzielny i rozsądny lub że oskarżony nie jest w stanie brać udziału w postępowaniu w sposób samodzielny i rozsądny. Potwierdzeniem takiego procesu wykładniczego, a jednocześnie wyrazem - w tym zakresie konsekwencji ustawodawcy jest treść $§ 4$ art. 79 k.p.k. Zgodnie ze wskazanym przepisem prawnym, „Uznając za uzasadnioną opinię biegłych lekarzy psychiatrów (...), że stan zdrowia psychicznego oskarżonego pozwala na udział w postępowaniu i prowadzenie obrony w sposób samodzielny i rozsądny, sąd orzeka, że udział obrońcy nie jest obowiązkowy". Podobnie stanowi przepis art. 202 $\S 5$ k.p.k., który wskazuje, że „opinia biegłych powinna zawierać stwierdzenia dotyczące zarówno poczytalności oskarżonego w chwili popełnienia zarzuconego mu czynu, jak i jego aktualnego stanu zdrowia psychicznego, a zwłaszcza wskazanie, czy stan ten pozwala oskarżonemu na udział w postępowaniu i na prowadzenie obrony w sposób samodzielny i rozsądny, a w razie potrzeby także

42 Np. gdy oskarżony pogrążony w depresji, fizycznie obecny na rozprawie, nie jest w stanie - ze względu na swój stan psychiczny - brać udziału w postępowaniu, np. z powodu trudności w zapamiętywaniu i odtwarzaniu informacji, nieumiejętności należytej komunikacji, posiadania problemów związanych z rozumieniem kierowanych do niego oświadczeń itd.

$43 \mathrm{~Np}$. gdy oskarżony ze względu na długoletnie zażywanie środków odurzających nie jest w stanie podejmować racjonalnych działań, np. przez intelektualne ograniczenia. 
stwierdzenia co do okoliczności wymienionych w art. 93b Kodeksu karnego". We wskazanych sytuacjach pomiędzy zaprezentowanymi zwrotami użyto spójnik „¡" wyrażający koniunkcję. Jest to zupełnie zasadne, ponieważ prawdziwość koniunkcji uzależniona jest od prawdziwości obu zdań składowych. Zatem aby doszło do uznania, że udział obrońcy w postępowaniu karnym nie jest obowiązkowy (naturalnie biorąc pod uwagę wskazaną powyżej jednostkę redakcyjną), należy uznać, że stan zdrowia oskarżonego pozwala na jego udział w postępowaniu w sposób samodzielny i rozsądny i jednocześnie, że może on prowadzić obronę w sposób samodzielny i rozsądny. Gdyby choć jedno z tych zdań było fałszywe, wówczas fałszywa byłaby koniunkcja tych zdań, a to z kolei uniemożliwiałoby uznanie, że udział obrońcy w tymże postępowaniu nie jest obowiązkowy.

Należy także zwrócić uwagę, że warunkiem zaistnienia obu wskazanych powyżej przesłanek jest udział w postępowaniu lub prowadzenie obrony w sposób samodzielny oraz rozsądny. Zwrot „samodzielny oraz rozsądny” jest przejawem koniunkcji ${ }^{44}$, zaś:

warunkiem wystarczającym i zarazem koniecznym prawdziwości koniunkcji jest prawdziwość obu zdań składowych. Natomiast fałszywość choćby jednego zdania składowego jest warunkiem wystarczającym fałszywości koniunkcji. Fałszywość obu zdań składowych nie jest warunkiem koniecznym fałszywości koniunkcji, gdyż już przy jednym zdaniu fałszywym całość jest fałszywa ${ }^{45}$.

Co za tym idzie, aby możliwe było zastosowanie obrony obligatoryjnej, oba warunki, a więc samodzielność i rozsądność w odniesieniu do udziału w postępowaniu lub prowadzenia obrony, muszą być spełnione łącznie. Zatem to łączne wypełnienie tych warunków implikuje konieczność zastosowania obrony obligatoryjnej na podstawie przepisu art. $79 \S 1$ pkt 4 k.p.k. A contrario, niewypełnienie jednego z tych warunków niweczy możliwość wyznaczenia obrony obligatoryjnej z urzędu w oparciu o wskazaną jednostkę redakcyjną. $\mathrm{Na}$ tym tle warto powziąć pewną wątpliwość, czy samodzielność oraz rozsądność - w kontekście zdrowia psychicznego oskarżonego - zawsze pozostają ze sobą w związku (a więc czy samodzielność zawsze implikuje rozsądność oraz czy rozsądność zawsze implikuje samodzielność). Wydaje się jednak, że ten zwią-

44 Koniunkcja ma postać słowną ,i”, „oraz”.

45 Z. Ziembiński, Logika.., s. 79. 
zek nie jest konieczny ${ }^{46}$. Innymi słowy, w niniejszym szkicu stoję na stanowisku, że można wyobrazić sobie sytuacje, w których stan zdrowia psychicznego oskarżonego pozwala mu na udział w postępowaniu lub prowadzenie obrony w sposób samodzielny, ale już nierozsądny, oraz takie sytuacje, w których stan zdrowia psychicznego oskarżonego pozwala mu na udział w postępowaniu lub prowadzenie obrony w sposób rozsądny, ale już niesamodzielny. Co za tym idzie, gdyby uznać słuszność tej tezy, należałoby także uznać, że - w powyżej wskazanych przypadkach - obrona obligatoryjna nie przysługiwałaby oskarżonemu (w oparciu o analizowaną w niniejszym miejscu przesłankę) $)^{47}$, co

46 Tytułem przykładu wydaje się (hipoteza), iż z sytuacją, w której dana osoba może bronić się w sposób rozsądny, lecz już niesamodzielny, mamy do czynienia w sytuacji, gdy występuje tzw. zespół czołowy. Jest to zespół objawów psychoorganicznych związanych z uszkodzeniem okolicy czołowej mózgu. W niektórych postaciach tego zespołu może dojść do deficytów uwagi, przypominania, myślenia abstrakcyjnego, myślenia przyczynowo-logicznego, ale też apatii czy utraty motywacji. Warto zwrócić uwagę, iż podstawowe umiejętności językowe i procesy poznawcze nie są zaburzone. W literaturze, w której opisuje się zespół czołowy, wskazywano, że: „Radykalna zmiana osobowości (...) polega na zaniku umiejętności podejmowania decyzji, na niemożności kierowania swoim losem, na utracie świadomej kontroli nad swoim życiem, przy zachodzeniu normalnego stanu intelektu". Tak: A. Herzyk, Neuropsychologiczna analiza zaburzeń emocjonalnych u pacjentów z zaburzeniami mózgu, „Audiofonologia” 1999, t. XIV, s. 31-32. Można przypuszczać, że osoba z zespołem czołowym - ze względu na niezmieniony stan intelektualny, a także zachowane umiejętności językowe i poznawcze - jest w stanie bronić się w sposób rozsądny, ale już samodzielność obrony takiej osoby może być wyłączona, np. z tego względu, że nie potrafi ona należycie kierować swoim życiem (a w tym i także nie potrafiłaby należycie kierować swoim życiem w związku z toczącym się postępowaniem karnym). Z kolei z sytuacją, w której dana osoba mogłaby bronić się w sposób samodzielny, ale nierozsądny, moglibyśmy mieć do czynienia w razie chorowania na depresję. Można wyobrazić sobie sytuację, w której oskarżony cierpiący na depresję potrafi samodzielnie podejmować wszystkie czynności procesowe, jednakże ich jakość, zakres, kompletność czy sposób wyrażania - powodowany złym stanem psychicznym - nie mógłby zostać uznany za rozsądny. Z podobną sytuacją możemy mieć do czynienia, gdy oskarżonym jest osoba w podeszłym wieku. Chciałam także podkreślić, iż podane powyżej przykłady są jedynie pewnymi hipotezami, które wcale nie muszą być prawdziwe, w zakresie w jakim wskazałam na związek tych zaburzeń psychicznych z prowadzeniem obrony lub udziałem w postępowaniu w sposób samodzielny czy rozsądny. Ewentualne przykłady takich sytuacji mogłyby zostać zaprezentowane przez psychologów i psychiatrów. Niemniej falsyfikacja przyjętego w niniejszym szkicu założenia, zgodnie z którym postępowanie w sposób samodzielny i rozsądny da się od siebie odseparować, mogłaby nastąpić, gdyby powszechnie uznawano, że jakaś osoba, która ze względu na stan zdrowia psychicznego nie może bronić się w sposób samodzielny, jednocześnie zawsze nie może bronić się w sposób rozsądny i na odwrót. Ponieważ takiego - jednoznacznego - poglądu nigdzie nie odnalazłam, stoję na stanowisku, iż stan zdrowia psychicznego danej osoby nie musi wykluczać sytuacji, w której może ona działać w sposób samodzielny, ale nierozsądny, lub gdy może ona działać w sposób rozsądny, ale niesamodzielny.

47 Z kolei można byłoby uznać, że taka sytuacja kwalifikowałaby się jako przesłanka do zastosowania obrony obligatoryjnej w oparciu o $§ 2$ art. 79 k.p.k. Jednakże takie ujęcie sprawy silnie rzutowałoby na celowość i zasadność wyodrębnienia przesłanki, o której mowa w art. 79 § 1 pkt 4 k.p.k. 
z pewnością byłoby dla tego uczestnika procesu karnego antygwarancyjne. Tak więc ustawodawca poprzez użycie koniunkcji pomiędzy wskazanymi zwrotami niedookreślonymi (,,samodzielny oraz rozsądny”) eliminuje z zakresu przesłanek obrony obligatoryjnej sytuacje, w których oskarżony ze względu na stan zdrowia psychicznego nie może prowadzić obrony w sposób samodzielny (ale może ją prowadzić w sposób rozsądny), sytuację, w której oskarżony nie może brać udział w postępowaniu w sposób samodzielny (ale może brać udział w postępowaniu w sposób rozsądny), sytuację, w której oskarżony nie może prowadzić obrony w sposób rozsądny (ale może ją prowadzić w sposób samodzielny), i sytuację, w której oskarżony nie może brać udziału w postępowaniu w sposób rozsądny (ale może brać udział w postępowaniu w sposób samodzielny). Te wszystkie sytuacje wykluczałyby możliwość zastosowania obrony obligatoryjnej na podstawie przepisu art. $79 \S 1$ pkt 4 k.p.k., albowiem brak w nich koniunkcji pomiędzy samodzielnością i rozsądnością. Można mieć pewne wątpliwości co do tego, czy taki był właśnie zamysł ustawodawcy we wskazanym zakresie ${ }^{48}$. Biorąc pod uwagę powyżej dokonane ustalenia, można uznać, że trudności w zastosowaniu przepisu art. 79 § 1 pkt 4 k.p.k. mogą wynikać zarówno z niedookreśloności i nieostrości pojęć w tym przepisie użytych, ale także z syntaktycznych połączeń w takim przepisie wysłowionych, a zatem zastosowanych przez ustawodawcę spójników reprezentujących alternatywę nierozłączną (zwykłą) oraz koniunkcję.

\section{Konkluzja}

Z powyżej zaprezentowanych rozważań wynika, że ustawodawca posługuje się w kodeksie postępowania karnego zwrotami niedookreślonymi (nieostrymi), co należy uznać za zabieg celowy oraz uzasadniony. Posługiwanie się takimi zwrotami związane jest bowiem z pozostawieniem pewnych luzów interpretacyjnych organom stosującym prawo. Nie oznacza to jednak, że w każdym przypadku zasługuje to na uwzględnienie. Interpretacja zamieszczonych w kodeksie postępowania karnego zwrotów niedookreślonych (nieostrych) powinna znajdować swoje rozwinięcie w opracowaniach naukowych, a także orzecznictwie sądowym. Językowa interpretacja przepisów kodeksu postępowania karnego ma tym większe znaczenie,

48 Jeżeli zamysłem ustawodawcy nie była - dla zastosowania obrony obligatoryjnej w oparciu o przepis art. 79 § 1 pkt 4 k.p.k. - konieczność łącznego wypełnienia kryterium samodzielności i rozsądności w kontekście udziału w postępowaniu lub prowadzenia obrony, to powinno dojść do językowej zmiany tego przepisu prawnego w postaci zmiany wskazanego spójnika. 
że oprócz charakterystyki zwrotów niedookreślonych (nieostrych) powinna następować także analiza syntaktycznych połączeń w takich przepisach wysłowionych. $\mathrm{Z}$ taką sytuacją mamy też do czynienia w związku z analizą treści przepisu art. 79 k.p.k. Warto zwrócić uwagę, iż językowe ustalenie kształtu tego przepisu prawnego ma doniosłe znaczenie także dla praktyki stosowania prawa, albowiem wiąże się z możliwością zastosowania przez organ procesowy obrony obligatoryjnej. $\mathrm{Na}$ zakończenie można przytoczyć znamienne słowa W. Woltera, które choć dotyczyły zwrotów o nieco odmiennym charakterze (tzw. zwrotów ilościowych), to jednak wpasowują się także w kontekst niniejszych rozważań. Jak twierdził Autor:

Niewątpliwie takie wyrazy ocenno-ilościowe ${ }^{49}$ bez ścisłego miernika nasuwają pewne wątpliwości, jako że rozluźniają one zawartość przepisu, czyniąc stosującego prawo w pewnym stopniu panem nad przepisem. Jednak zgodzić się musimy z tym, że zupełne wyłączenie takich znamion jest niemożliwe, zaś - gdy to jest w ogóle możliwe - zastąpienie przez ostre, liczbowe, nie bardzo pociągające. Wobec tego należy baczyć tylko na to, aby tych znamion nie było za wiele i ich układ był możliwie uporządkowany ${ }^{50}$

\section{Literatura}

Chodun A., Stownictwo tekstów aktów prawnych w zasobie leksykalnym wspótczesnej polszczyzny, Warszawa 2007.

Chodun A., Klauzule generalne i zwroty niedookreślone - wybrane zagadnienia teoretyczne, w: A. Chodun, A. Gomułowicz, A. Skoczylas, Klauzule generalne i zwroty niedookreślone $w$ prawie podatkowym $i$ administracyjnym. Wybrane zagadnienia teoretyczne i orzecznicze, Warszawa 2013.

Chodun A., Zieliński M., $W$ sprawie stowników w procesie interpretacji tekstów prawnych raz jeszcze, „Państwo i Prawo” 2008, z. 7.

Dąbkiewicz K., Kodeks postępowania karnego. Komentarz do zmian 2015, Warszawa 2015.

Długosz J., Ustawowa wyłaczność i określoność w prawie karnym, Warszawa 2016.

Drabik L., Kubiak-Sokół A., Sobol E., Wiśniakowska L., Słownik języka polskiego PWN, Warszawa 2006.

Habzda-Siwek E., Dylematy zwiazane z opiniq o stanie zdrowia psychicznego oskarżonego (refleksje wokót art. 202 k.p.k.), w: Nauki penalne wobec problemów wspótczesnej przestępczości. Księga jubileuszowa z okazji 70 rocznicy urodzin Profesora Andrzeja Gaberle, red. K. Krajewski, Warszawa 2007.

$49 \mathrm{~W}$ odniesieniu do niniejszego szkicu będą to zwroty niedookreślone.

50 W. Wolter, Uwagi o znamionach..., s. 33. 
Herzyk A., Neuropsychologiczna analiza zaburzeń emocjonalnych u pacjentów z zaburzeniami mózgu, „Audiofonologia” 1999, t. XIV.

Ksiega jubileuszowa Profesora Janusza Tylmana, red. T. Grzegorczyk, Warszawa 2011. Jadocka H., Przyczyny i skutki niejasności tekstów prawnych, w: Współczesny język prawny i prawniczy, red. A. Niewiadomski, A. Mróz, M. Pawelec, Warszawa 2007.

Kmiecik R., O poczytalności oskarżonego w „,czasie postępowania”-polemicznie, „Palestra" 2007, nr 5-6.

Nauki penalne wobec problemów współczesnej przestępczości. Księga jubileuszowa z okazji 70 rocznicy urodzin Profesora Andrzeja Gaberle, red. K. Krajewski, Warszawa 2007.

Obrońca i petnomocnik w procesie karnym po 1 lipca 2015 r. Przewodnik po zmianach, red. P. Wiliński, Warszawa 2015.

Paprzycki R., Glosa do wyroku SN z dnia 14 marca 2008r., II KK 404/04, „Palestra” 2005, nr 9-10.

Płatek A., Poczytalność oskarżonego „w czasie postępowania” czy psychiczna zdolność „,do rozumnej obrony”, „Palestra” 2009, nr 5-6.

Skorupka J., Kodeks postępowania karnego. Komentarz, Warszawa 2016.

Stefański R.A., Ustanie obrony obowiazkowej, „Państwo i Prawo” 2007, z. 9.

Stefański R.A., Obrona obligatoryjna w polskim procesie karnym, Warszawa 2012.

Stefański R.A., Obrona obligatoryjna po 1 lipca 2015 r., w: Obrońca i petnomocnik w procesie karnym po 1 lipca 2015 r. Przewodnik po zmianach, red. P. Wiliński, Warszawa 2015.

Świecki D., Czynności procesowe obrońcy i petnomocnika w sprawach karnych, Warszawa 2016.

Wolter W., Z problematyki języka prawnego kodeksu karnego, „Krakowskie Studia Prawnicze" 1972, rok V.

Wolter W., Uwagi o znamionach wymagajacych ilościowej oceny w przepisach prawa karnego, „Państwo i Prawo” 1976, nr 6.

Wronkowska S., Problemy racjonalnego tworzenia prawa, Poznań 1982.

Wronkowska S., Zieliński M., Zasady techniki prawodawczej. Komentarz, Warszawa 1997.

Wróblewski W., Kontrola decyzji sądowej - wybrane zagadnienia teoretyczne, „Państwo i Prawo" 1976, z. 8-9.

Współczesny język prawny i prawniczy, red. A. Niewiadomski, A. Mróz, M. Pawelec, Warszawa 2007.

Zbrojewska M., Obrona obligatoryjna zwiąana ze stanem psychiki oskarżonego (refleksje wokót art. 79 § 4 k.p.k.), w: Księga jubileuszowa Profesora Janusza Tylmana, red. T. Grzegorczyk, Warszawa 2011.

Zieliński M., Wykładnia prawa. Zasady. Reguły. Wskazówki, Warszawa 2002. 
Ziembiński Z., O czym mówia prawnicy, gdy mówia o „ocenach”, „Państwo i Prawo” 1986, z. 12.

Ziembiński Z., Logika praktyczna, Warszawa 2002.

Ziębiński A., Wybrane kontrowersje wokół obrony obligatoryjnej (cz. I), „Palestra” 2007, nr 1-2.

\title{
PHRASES UNDETERMINED DESCRIBING THE MENTAL HEALTH OF THE ACCUSED AND THE USE OF OBLIGATORY DEFENCE
}

\begin{abstract}
Summary
This article presents the reasons for the use of obligatory defense, reffered to in art. 79 of the Polish Code of Criminal Procedure, especially in $\S 1$ p. 4, from a linguistic perspective. Art. 79 k.p.k. contains phrases undetermined which describe the mental health of the accused. Their identification in a criminal trial obliges the court to appoint an official defender. The author considers the linguistic correctness of these indetermined phrases.
\end{abstract}

Keywords: accused, obligatory defense, indeterminate, sanity, mental health condition, phrases undetermined 